\title{
Institutional Ground Serves as A Safe Haven for Birds, Butterflies and Odonates - A Case Study from Kolkata
}

\author{
Soma Aditya (Bandyopadhyay) \\ Department of Zoology, Sarojini Naidu College for Women, 30, Jessore Road, Dum Dum, Kolkata - 700028 , \\ West Bengal, India.
}

Correspondence E-mail : somaadityabandyopadhyay@gmail.com

\begin{abstract}
Urban biodiversity has received very little importance from environmentalists in comparison to natural and protected ecosystems. Much of our native birds, butterflies and odonates are fast disappearing due to habitat destruction in urban environment and unscientific management of our natural resources and at present, their survival is under threat. The objective of the present review is focussed on the assessment of the diversity of butterflies, birds and odonates with vegetation composition of habitat and conservation priorities in a college campus. A combination of direct search and opportunistic sighting methods were applied to record 49 species of butterflies under 5 families and 36 genera, 45 species of birds belonging to 12 orders and 25 families and 23 different Odonata species (18 dragonflies and 5 damselflies) from the study area during the period 2014-2016. Our observation emphasizes that the institutional campus fulfils an environment favourable for harbouring a rich and diverse fauna. This study aims to focus on creation of a comprehensive biodiversity management program to properly monitor the diverse flora, fauna as well as the habitat in and around the college ground.
\end{abstract}

Keywords: bird, butterfly, Odonata, biodiversity, conservation.

\section{Introduction}

The Indian subcontinent presents extremely diverse climate, terrain and vegetation owing to which there is tremendous diversity of flora and fauna. It has been estimated that our country harbors about 1,300 species of birds (Grimmett et al. 1988, Ali S. 2002). 1504 species of butterflies (Tiple AD 2011) and 474 species of Odonates (Subramanian 2014). Being very sensitive towards any type of change in their habitat, avian species assemblages, odonates and butterflies are considered potent indicators of ecosystem health and functioning. Butterflies enable sustenance of ecosystem services through their role in pollination (Nair et al. 2014). Butterflies and Odonates play significant role as important food chain components. Thus, exploration of avifauna as well as lepidopterans and odonates become important in identifying and preserving potential habitats under threat.

The well-being of humans has always been inexorably linked to the health of our local environments. Unfortunately, urban biodiversity has received very little importance from environmentalists as compared to natural and protected ecosystems. In urban ecosystems, species diversity assessment can be used as a means to reduce human misconduct and pollution in industrial, rural, and managed areas (Reaka-Kudla et al. 1997). Taking this into consideration, diversity 
studies in urban ecosystems are important to understand the effect of anthropocentric development on the sustenance of ecosystem.

Of late, we are rapidly losing greenery in the name of development. There has also been an alarming rise in industrial and automobile pollution in Indian metropolitan cities (Nair et al. 2014). With the shrinking of greenery and increase in pollution, butterflies, birds and all our wildlife are fast disappearing. The net result is a complete imbalance of the ecosystem and extinction of many species (Nair et al. 2014). In spite of the fast growth, Indian cities still have diverse serene habitats such as the traffic island gardens in the middle of busy roads, parks or urban forest areas with mixed deciduous and non-deciduous trees and scrubland serving as ideal habitats for various types of wildlife, especially butterflies, birds and Odonata. Institutional campuses with seasonal flowering plantation and undisturbed natural vegetation provide potential habitat for bird and insect population as they are devoid of any developmental activities and pollution (Tiple et al. 2006; 2007; Tiple AD 2012; Mohapatra et al. 2013; DasGupta \& Rao 2014; Jain et al. 2005; Wadatkar JS 2001; Dey et al. 2013; Reginald et al. 2014).

Sarojini Naidu College for Women (SNCW), Dum Dum, $\left(22^{\circ} 37^{\prime} 12^{\prime \prime} \mathrm{N}\right.$ and $\left.88^{\circ} 25^{\prime} 12^{\prime \prime} \mathrm{E}\right)$ is located in a sub-urban belt having a wellwooded campus amidst a mosaic of concrete buildings (Nair et al. 2014) (Image. 1).

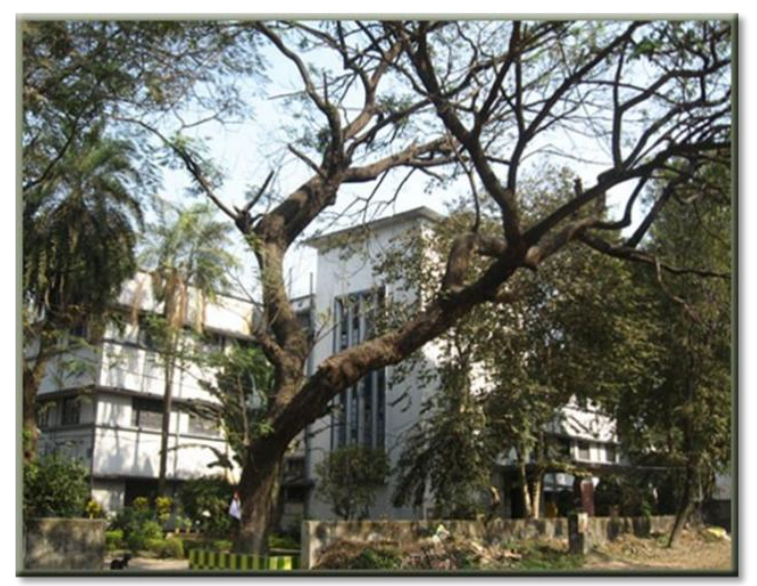

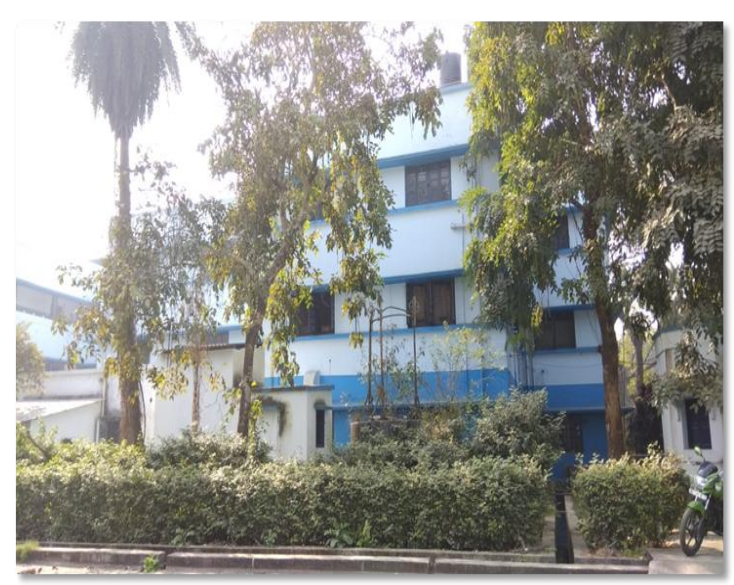
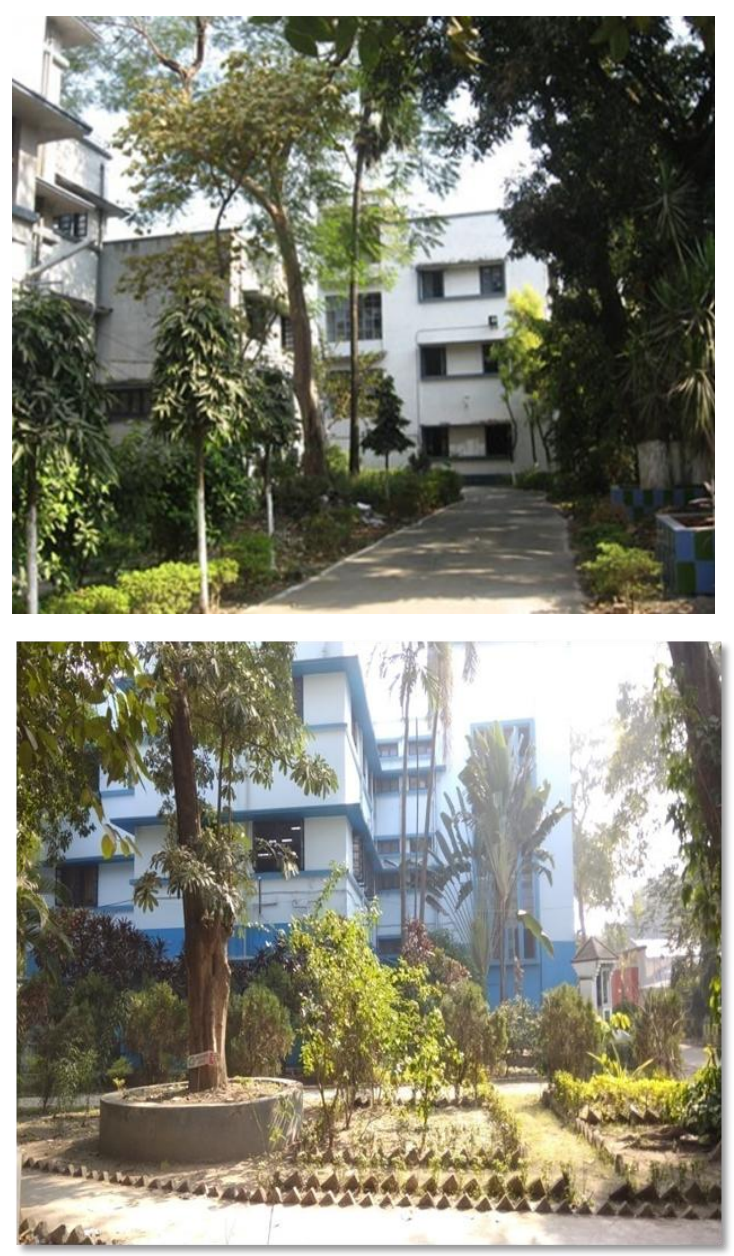

Image 1. Photographs of the college campus taken from different angles

The campus is spread over an area of 3.5 acres with lush green vegetation having large trees, bushy shrubs and long grasses that provide shelter to the butterflies, birds and Odonates (Image. 2). 


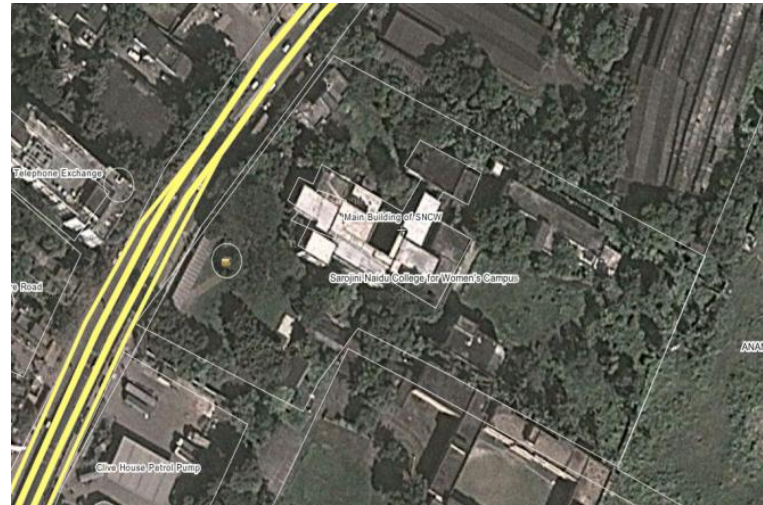

Image 2. Satellite overview map of study locality

There are also ponds and water bodies with rich aquatic vegetation in the vicinity of the college (Mandal \& Aditya 2017). The study area experiences a sub-tropical climate with hot summers from late March to early June (Temperature range: $25^{\circ} \mathrm{C}-40^{\circ} \mathrm{C}$ ), the humid monsoon season from mid June to late September and a cool dry winter from late November to early February (temperature range: $12^{\circ} \mathrm{C}-25^{\circ} \mathrm{C}$ ). Humidity is generally very high during summer and the area receives an average rainfall of $170 \mathrm{~mm}$ (Nair et al. 2014). This study is aimed towards contributing to the plan of biodiversity restoration in our campus and development of management strategies so as to ensure sustenance of birds, butterflies and Odonates and ecosystem services derived from them.

\section{Materials and Methods}

The findings presented here are based on random surveys carried out for a consecutive period of three years, from 2014-2016. The total college campus was surveyed for butterflies, birds and Odonates in the morning, noon and evening times with the help of a Bushnell binocular $(8 \times 40)$ and photographed with a digital camera in their natural habitats. All scientific names of the butterflies followed in the present study are in accordance with Varshney R K (1983) and common English names follow Wynter-Blyth M A(1957). Bird identifications were based according to Grimmett et al. (1998) and Ali, S (2002). The Odonates were identified upto the species level following Subramanian (2014).

\section{Results}

The present study represented the avian, lepidopteran and odonate community structure of SNCW College campus and its surroundings of North 24 Parganas district of West Bengal. Forty nine species of butterflies representing five families and thirty six genera have been recorded during the study (Nair et al. 2014) (Table 1).

Table 1: List of butterflies recorded from SNCW campus

\begin{tabular}{|c|c|c|}
\hline $\begin{array}{l}\text { SI. } \\
\text { No. }\end{array}$ & Common Name & Scientific Name \\
\hline 1. & Common mormon & $\begin{array}{l}\text { Papilio polytes } \\
\text { Linnaeus }\end{array}$ \\
\hline 2. & Spot swordtail & $\begin{array}{l}\text { Graphium nomius } \\
\text { (Esper) }\end{array}$ \\
\hline 3. & Common jay & $\begin{array}{c}\text { Graphium doson (C. \& } \\
\text { R. Felder) }\end{array}$ \\
\hline 4. & Lime butterfly & $\begin{array}{l}\text { Papilio demoleus } \\
\text { Linnaeus }\end{array}$ \\
\hline 5. & Tailed jay & $\begin{array}{c}\text { Graphium agamemnon } \\
\text { (Linnaeus) }\end{array}$ \\
\hline 6. & Blue mormon & $\begin{array}{c}\text { Papilio polymnestor } \\
\text { Cramer }\end{array}$ \\
\hline 7. & Blue pansy & $\begin{array}{l}\text { Junonia orithiya } \\
\text { (Linnaeus) }\end{array}$ \\
\hline 8. & Commander & $\begin{array}{l}\text { Moduza procris } \\
\text { (Cramer) }\end{array}$ \\
\hline 9. & Striped tiger & $\begin{array}{l}\text { Danaus genutia } \\
\text { (Cramer) }\end{array}$ \\
\hline 10. & Common castor & $\begin{array}{l}\text { Ariadne merione } \\
\text { (Cramer) }\end{array}$ \\
\hline 11. & Common palmfly & $\begin{array}{c}\text { Elymnias } \\
\text { hypermnestra } \\
\text { (Linnaeus) }\end{array}$ \\
\hline 12. & Grey pansy & $\begin{array}{l}\text { Junonia atlites } \\
\text { (Linnaeus) }\end{array}$ \\
\hline 13. & Lemon pansy & $\begin{array}{l}\text { Junonia lemonias } \\
\text { (Linnaeus) }\end{array}$ \\
\hline 14. & Tawny coster & $\begin{array}{c}\text { Acraea violae } \\
\text { (Fabricius) }\end{array}$ \\
\hline 15. & Glassy tiger & Parantica aglea (Stoll) \\
\hline 16. & Great eggfly & $\begin{array}{l}\text { Hypolimnas bolina } \\
\text { (Linnaeus) }\end{array}$ \\
\hline 17. & Common crow & Euploea core (Cramer) \\
\hline 18. & Plain tiger & $\begin{array}{l}\text { Danaus chrysippus } \\
\text { (Linnaeus) }\end{array}$ \\
\hline 19. & $\begin{array}{l}\text { Common } \\
\text { bushbrown }\end{array}$ & $\begin{array}{c}\text { Mycalesis perseus } \\
\text { (Fabricius) }\end{array}$ \\
\hline 20. & Peacock pansy & $\begin{array}{l}\text { Junonia almana } \\
\text { (Linnaeus) }\end{array}$ \\
\hline 21. & Common baron & Euthalia aconthea \\
\hline
\end{tabular}


Int J Adv Life Sci Res. Volume 3(4) 09-16

\begin{tabular}{|c|c|c|}
\hline & & (Cramer) \\
\hline 22. & Blue tiger & $\begin{array}{l}\text { Tirumala limniace } \\
\text { (Cramer) }\end{array}$ \\
\hline 23. & Common fourring & $\begin{array}{l}\text { Ypthima huebneri } \\
\text { Kirby }\end{array}$ \\
\hline 24. & $\begin{array}{c}\text { Common evening } \\
\text { brown }\end{array}$ & $\begin{array}{l}\text { Melanitis leda } \\
\text { (Linnaeus) }\end{array}$ \\
\hline 25. & Common fivering & $\begin{array}{l}\text { Ypthima baldus } \\
\text { (Fabricius) }\end{array}$ \\
\hline 26. & $\begin{array}{c}\text { Chestnut- } \\
\text { streaked sailer }\end{array}$ & Neptis jumbah Moore \\
\hline 27. & $\begin{array}{c}\text { Common grass } \\
\text { yellow }\end{array}$ & $\begin{array}{l}\text { Eurema hecabe } \\
\text { (Linnaeus) }\end{array}$ \\
\hline 28. & Psyche & $\begin{array}{l}\text { Leptosia nina } \\
\text { (Fabricius) }\end{array}$ \\
\hline 29. & Common jezebel & Delias eucharis (Drury) \\
\hline 30. & Striped albatross & $\begin{array}{l}\text { Appias libythea } \\
\text { (Fabricius) }\end{array}$ \\
\hline 31. & Mottled emigrant & $\begin{array}{l}\text { Catopsilia pyranthe } \\
\text { (Linnaeus) }\end{array}$ \\
\hline 32. & $\begin{array}{l}\text { Common } \\
\text { emigrant }\end{array}$ & $\begin{array}{l}\text { Catopsilia pomona } \\
\text { (Fabricius) }\end{array}$ \\
\hline 33. & Yellow orange tip & $\begin{array}{l}\text { Ixias pyrene } \\
\text { (Linnaeus) }\end{array}$ \\
\hline 34. & $\begin{array}{l}\text { Striped albatross } \\
\text { 'olferna' }\end{array}$ & Appias olferna \\
\hline 35. & $\begin{array}{c}\text { Indian cabbage } \\
\text { white }\end{array}$ & $\begin{array}{l}\text { Pieris canidia } \\
\text { (Sparrman) }\end{array}$ \\
\hline 36. & $\begin{array}{c}\text { Three spot grass } \\
\text { yellow }\end{array}$ & $\begin{array}{l}\text { Eurema blanda } \\
\text { (Boisduval) }\end{array}$ \\
\hline 37. & $\begin{array}{l}\text { Long-banded } \\
\text { silverline }\end{array}$ & $\begin{array}{l}\text { Spindasis lohita } \\
\text { (Horsfield) }\end{array}$ \\
\hline 38. & Common pierrot & $\begin{array}{l}\text { Castalius rosimon } \\
\text { (Fabricius) }\end{array}$ \\
\hline 39. & Plains cupid & $\begin{array}{c}\text { Chilades pandava } \\
\text { (Horsfield) }\end{array}$ \\
\hline 40. & Tiny grass blue & Zizula hylax (Fabricius) \\
\hline 41. & Lime blue & Chilades lajus (Stoll) \\
\hline 42. & $\begin{array}{l}\text { Common } \\
\text { cerulean }\end{array}$ & $\begin{array}{l}\text { Jamides celeno } \\
\text { (Cramer) }\end{array}$ \\
\hline 43. & Dark grass blue & $\begin{array}{c}\text { Zizeeria karsandra } \\
\text { (Moore) }\end{array}$ \\
\hline 44. & Pale grass blue & $\begin{array}{c}\text { Pseudozizeeria maha } \\
\text { (Kollar) }\end{array}$ \\
\hline 45. & Apefly & $\begin{array}{l}\text { Spalgis epius } \\
\text { (Westwood) }\end{array}$ \\
\hline 46. & Tailless lineblue & $\begin{array}{l}\text { Prosotas dubiosa } \\
\text { indica Evans }\end{array}$ \\
\hline 47. & Forget-me-not & $\begin{array}{l}\text { Catochrysops strabo } \\
\text { (Fabricius) }\end{array}$ \\
\hline 48. & Gram blue & $\begin{array}{l}\text { Euchrysops cnejus } \\
\text { (Fabricius) }\end{array}$ \\
\hline 49. & $\begin{array}{c}\text { Small branded } \\
\text { swift }\end{array}$ & $\begin{array}{l}\text { Pelopidas mathias } \\
\text { (Fabricius) }\end{array}$ \\
\hline
\end{tabular}

The maximum species richness was shown by Nymphalidae comprising of 20 species (41\%), followed by Lycaenidae (12 species, 25\%), Pieridae (10 species, 20\%), Papilionidae (6 species, 12\%) and Hesperiidae (1 species, $2 \%$ ). Common mormon, Lime butterfly and Psyche were found in high frequencies among all the recorded butterfly species in the campus. A total of five species of butterflies from the study area were designated rare, suggesting the need for strict conservation measures. Two species, Common pierrot and Chestnut-streaked sailer belong to Schedule I, Long-banded silverline and Gram blue belonged to Schedule II and Striped Albatross belongs to Schedule IV of the Indian Wildlife (Protection) Act, 1972 (Nair et al. 2014).

The study depicted the presence of 45 species of birds belonging to 12 orders and 25 families (Das \& Aditya 2016) (Table 2). Order Passeriformes represented by 17 species belonging to 12 families contribute to about 38 $\%$ of the total avifaunal species richness. Among the non-passerines, maximum richness was represented by the order Pelicaniformes (5 species) and order Piciformes (4 species) followed by Columbiformes, Cuculiformes and Coraciformes (3 species of each) (Table 1). The Ardeidae family shows the highest species richness (5 species) within the campus followed by Sturnidae, Cuculidae and Columbidae (3 species of each) (Das \& Aditya 2016) (Table 2).

A total of 23 species of Odonata representing 19 genera from 5 families was recorded from Sarojini Naidu College campus and its vicinity (Mandal \& Aditya 2017) (Table 3 \& 4). The most diverse and abundant family was Libellulidae among the dragonflies (suborder Anisoptera), represented by 15 species (65.21\%) followed by Aeshnidae (2 species) and Gomphidae (1 species) while among damselflies (suborder Zygoptera), Coenagrionidae was the most dominant family represented by 4 species (17.39\%) followed by Platycenemididae representing 1 species $(4.34 \%)$ only. Orthetrum pruinosum was the most abundant species recorded in the study area (Mandal \& Aditya 2017). 
Int J Adv Life Sci Res. Volume 3(4)09-16

Aditya S.

Table 2 : List of birds recorded from SNCW campus

\begin{tabular}{|c|c|c|c|}
\hline ORDER & FAMILY & COMMON NAME & SCIENTIFIC NAME \\
\hline \multirow{17}{*}{ Passeriformes } & Passeridae & House Sparrow & Passer domesticus \\
\hline & \multirow{2}{*}{ Corvidae } & House Crow & Corvus splendens \\
\hline & & Rufous Tree Pie & Dendrocitta vagabunda \\
\hline & \multirow{2}{*}{ Muscicapidae } & Oriental Magpie Robin & Copsychus saularis \\
\hline & & Red breasted Flycatcher & Ficedula parva \\
\hline & Dicruridae & Black Drongo & Dicrurus macrocercus \\
\hline & Pycnonotidae & Red Vented Bulbul & Pycnonotus cafer \\
\hline & Oriolidae & Black Hooded Oriole & Oriolus xanthornus \\
\hline & \multirow{3}{*}{ Sturnidae } & Common Myna & Acridotheres tristis \\
\hline & & Asian Pied Starling & Gracupica contra \\
\hline & & Jungle Myna & Acridotheres fuscus \\
\hline & Sylvidae & Common Tailorbird & Orthotomus sutorius \\
\hline & \multirow{2}{*}{ Nectariniidae } & Purple sunbird & Cinnyris asiaticus \\
\hline & & Purple Rumped Sunbird & Leptocoma zeylonica \\
\hline & Timaliidae & Jungle babbler & Turdoides striata \\
\hline & Aegithinidae & Common Iora & Aegithina tiphia \\
\hline & Paridae & Great Tit & Parus major \\
\hline \multirow{3}{*}{ Columbiformes } & \multirow{3}{*}{ Columbidae } & Yellow Footed Green Pigeon & Treron phoenicopterus \\
\hline & & Spotted Dove & Stigmatopelia chinensis \\
\hline & & Common Pigeon & Columba livia \\
\hline Psittaciformes & Psittacidae & Rose-ringed Parakeet & Psittacula krameri \\
\hline \multirow{3}{*}{ Cuculiformes } & \multirow{3}{*}{ Cuculidae } & Common Hawk Cuckoo & Hierococcyx varius \\
\hline & & Asian Koel & Eudynamys scolopaceus \\
\hline & & Greater Coucal & Centropus sinensis \\
\hline \multirow{2}{*}{ Falconiformes } & \multirow{2}{*}{ Accipitridae } & Shikra & Accipiter badius \\
\hline & & Steppe eagle & Aquila nipalensis \\
\hline \multirow{2}{*}{ Strigiformes } & \multirow{2}{*}{ Strigidae } & Spotted Owlet & Athene brama \\
\hline & & Barn Owl & Tyto alba \\
\hline \multirow{4}{*}{ Piciformes } & \multirow{2}{*}{ Picidae } & Streak Throated Woodpecker & Picus xanthopygaeus \\
\hline & & Lesser Goldenback & Dinopium benghalense \\
\hline & \multirow{2}{*}{ Ramphastidae } & Coppersmith Barbet & Megalaima haemacephala \\
\hline & & Blue-Throated Barbet & Megalaima asiatica \\
\hline \multirow{2}{*}{ Suliformes } & \multirow{2}{*}{ Phalacrocoracidae } & Little Cormorant & Phalacrocorax niger \\
\hline & & Great Cormorant & Phalacrocorax carbo \\
\hline \multirow{5}{*}{ Pelicaniformes } & \multirow{5}{*}{ Ardeidae } & Black-Crowned Night Heron & Nycticorax nycticorax \\
\hline & & Indian pond Heron & Ardeola grayii \\
\hline & & Cattle Egret & Bubulcus ibis \\
\hline & & Great Egret & Casmerodius albus \\
\hline & & Little Egret & Egretta garzetta \\
\hline Gruiformes & Rallidae & White Breasted Waterhen & Amaurornis phoenicurus \\
\hline \multirow{2}{*}{ Apodiformes } & \multirow{2}{*}{ Apodidae } & Asian Palm Swift & Cypsiurus balasiensis \\
\hline & & House Swift & Apus affinis \\
\hline \multirow{3}{*}{ Coraciformes } & \multirow{2}{*}{ Alcedinidae } & Stork Billed Kingfisher & Pelargopsis capensis \\
\hline & & White Throated Kingfisher & Halcyon smyrnensis \\
\hline & Meropidae & Green Bee-Eater & Merops orientalis \\
\hline
\end{tabular}

Table: 3. List of damselflies (sub order- Zygoptera) of SNCW

\begin{tabular}{|l|l|l|l|}
\hline $\begin{array}{l}\text { Sl. } \\
\text { no. }\end{array}$ & \multicolumn{1}{|c|}{ Family } & Common name & Scientific name \\
\hline 1 & Coenagrionidae & Pigmy Dartlet & Agriocnemis pygmaea (Rambur, 1842) \\
\hline 2 & & Coromandel Marsh Dart & Ceriagrion coromandelianum (Fabricius, 1798) \\
\hline 3 & & Golden Dartlet & Ischnura aurora (Brauer,1865) \\
\hline 4 & & Saffron-faced Blue Dart & Pseudagrion rubriceps Selys, 1876 \\
\hline 5 & Platycnemididae & Yellow Bush Dart & Copera marginipes (Rambur, 1842) \\
\hline
\end{tabular}


Int J Adv Life Sci Res. Volume 3(4)09-16

Aditya S.

Table: 4. List of dragonflies (sub order- Anisoptera) of SNCW

\begin{tabular}{|c|l|l|l|}
\hline Sl.no & Family & Common Name & Scientific Name \\
\hline 1 & Aeshnidae & Blue-tailed Green Darner & Anax guttatus (Burmeister, 1839) \\
\hline 2 & & Brown Darner & Gynacantha dravida Lieftinck, 1960 \\
\hline 3 & Gomphidae & Common Club Tail & Ictinogomphus rapax (Rambur, 1842) \\
\hline 4 & Libellulidae & Scarlet Marsh Hawk & Aethriamanta brevipennis (Rambur, 1842) \\
\hline 5 & & Rufous Marsh Glider & Rhodothemis rufa (Rambur, 1842) \\
\hline 6 & & Ditch Jewel & Brachythemis contaminata (Fabricius,1793) \\
\hline 7 & & Ruddy Marsh Skimmer & Crocothemis servilia (Drury, 1770) \\
\hline 8 & & Black-tipped Ground Skimmer & Diplacodes nebulosa (Fabricius,1793) \\
\hline 9 & & Ground Skimmer & Diplacodes trivialis (Rambur, 1842) \\
\hline 10 & & Fulvous Forest Skimmer & Neurothemis fulvia (Drury, 1773) \\
\hline 11 & & Pied Paddy Skimmer & Neurothemis tullia (Drury, 1773) \\
\hline 12 & & Blue Marsh Hawk & Orthetrum glaucum (Brauer,1865) \\
\hline 13 & & Crimson-tailed Marsh Hawk & Orthetrum pruinosum (Burmeister,1839) \\
\hline 14 & & Green Marsh Hawk & Orthetrum sabina (Drury, 1770) \\
\hline 15 & & Wandering Glider & Pantala flavescens (Fabricius,1798) \\
\hline 16 & & Common Picture Wing & Rhyothemis variegata (Linnaeus, 1763) \\
\hline 17 & & Crimson Marsh Glider & Trithemis aurora (Burmeister, 1839) \\
\hline 18 & & Rufous-backed Marsh Hawk & Brachydiplax chalybea (Brauer, 1868) \\
\hline
\end{tabular}

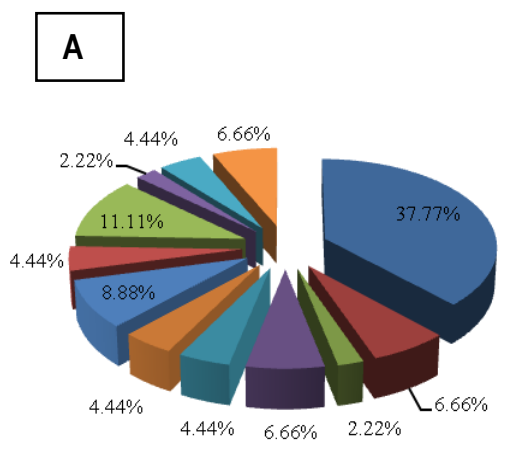

$$
\begin{aligned}
& \text { - Passeriformes } \\
& \text { - Columbiformes } \\
& \text { - Psittaciformes } \\
& \text { - Cuculiformes } \\
& \text { - Falconiformes } \\
& \text { - Strigiformes } \\
& \text { - Piciformes } \\
& \text { - Suliformes } \\
& \text { - Pelicaniformes } \\
& \text { - Gruiformes } \\
& \text {-Apodiformes } \\
& \text { - Coraciformes }
\end{aligned}
$$

$$
\text { B }
$$

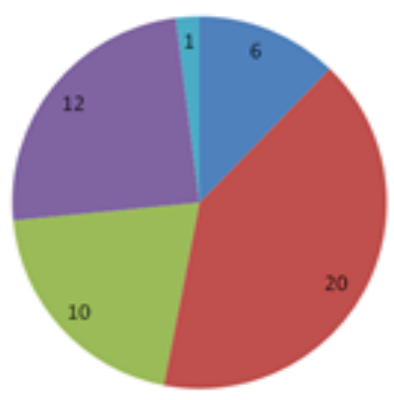

E Papilionidae

nymphalidae

n Pieridae

n Lycaenidae

nesperiidae

\section{C}

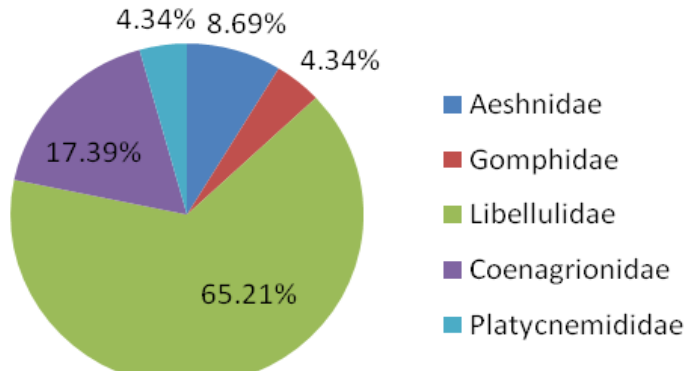

Fig - A, B and C represents percentage composition of Bird, Butterfly and Odonata species in different families at SNCW campus, Kolkata

\section{Discussion}

College campuses usually are not thought of as key areas for the preservation of biotic resources. Campuses do not enjoy the formal protection of national parks and nature preserves (Wheeler A G 2008). They consist largely of human-modified landscapes and are the habitat fragments of highly diverse 
ecosystems and the corridors that link them. Thus, it is important to maintain this connectivity in order to sustain the rich faunal diversity on the campus. Although educational grounds occupy less than $5 \%$ of the total urban area, such areas may harbor up to half the biodiversity of the urban biota due to undisturbed natural vegetation (Mohapatra et al. 2013; DasGupta \& Rao 2014; Jain et al. 2005; Wadatkar JS 2001; Dey et al. 2013; Reginald et al. 2014). Our observation emphasizes the importance of urban green spaces in conserving regional biodiversity as the area houses 49 species of butterflies [5], 45 species of birds (Das \& Aditya 2016) and 23 species of Odonates (Mandal \& Aditya 2017). Such high diversity and abundance in urban areas may be attributed to the grasslands, shrubs and small water bodies in and around the campus with minimal disturbance.

The distribution and occurrence of avifauna, Lepidopterans and Odonates correlate well with the vegetation pattern of the area. The preference of butterflies for particular habitats is associated with the availability of larval host plants and adult nectar plants. The flora in our campus is a mixed type with herbs and shrubs dominating the vegetation in the tropical climate (Nair et al. 2014). Trees are comparatively lesser in number. The study area is dominated by plant species belonging to families Annonaceae, Apocynaceae, Fabaceae, Malvaceae, Acanthaceae, Rubiaceae etc. namely Ficus sp, Calotropis $\mathrm{sp}$, Tridax sp, Polyalthia longifolia, Cassia fistula, Citrus sp, Terminalia arjuna, Murraya sp, Psidium guajava, Areca catechu, Cocos nucifera, Mangifera indica, Tabernaemontana sp, Alstonia scholaris, Ixora sp, Lantana camara, Cleome viscosa, Aegle sp, Hibiscus $s p$, Zizyphus jujuba, Justicia sp, Sida sp, Nerium sp, Mussaenda frondosa, Cosmos $s p$, Zinnia sp, Bougainvillea sp and grasses which provide diverse habitat, nesting, feeding and breeding sites for birds and butterflies (Nair et al. 2014).

The study area, despite small in size, appears to support an extremely rich and diverse faunal community because the dimension of the green space and the amount of tree cover are critical factors supporting biodiversity in urban environments. However, anthropogenic interference, developmental activities, and trimming of plants during breeding season were identified as some of the threats to biodiversity in the college campus. In addition to these, a variety of threats from human recreational and developmental activities, trampling, run-off from roads, litter deposition and weeds, sound pollution, feral dogs are common factors which affect bird, butterfly and Odonate populations (Das \& Aditya 2016).

Urbanization in cities has generated many small, isolated fragmented patches which can be exploited for the conservation of local flora and fauna. Such green patches in the highly industrialized and polluted landscape of Kolkata indicate the potentiality of the habitat to support a substantial amount of biodiversity. Similar habitation need to be identified in other urban centres in West Bengal as well as India and development of long-term protection and management are required for conserving regional biodiversity. With the pressing needs of the growing human population in India, natural greeneries are being clear-felled giving way to urbanization, pollution and overgrazing. Loss of prime habitat is the major threat to all wildlife including butterflies, birds and Odonates (Nair et al. 2014). Although we cannot completely nullify the ill effects of urbanization and development, we can at least try to reduce them by planting endemic trees and plants supporting the local wildlife. This will make sure that at least the common species will not go on to the verge of extinction (Nair et al. 2014).

\section{Conclusion}

The findings of the present study underline the importance of institutional campuses as a preferred habitat for birds, butterflies and odonates. Our results highlighted that a small compact area like a segregated college campus supports a diverse fauna. If the landscaping and maintenance of the gardens within the campus are carefully planned, the diversity of wildlife may increase providing a rich ground for conservation as well as for research. Further, human interference and developmental activities should not increase in the area over a period of time to maintain diverse species composition. 


\section{Acknowledgments:}

The author is grateful to the Principal, Sarojini Naidu College for Women, Dum Dum, West Bengal, India for providing amenities to carry out the survey work in the college campus.

\section{References}

Ali, S. (2002). The Book of Indian Birds. Oxford University Press, New Delhi.

Das, P. and Aditya (Bandyopadhyay), S. (2016). A preliminary assessment of avifaunal diversity in and around Sarojini Naidu College campus, Kolkata, West Bengal, India. International Journal of Fauna and Biological Studies, 3(2), 56-61.

Dasgupta, N., Rao, R.J. (2014). Diversity and seasonal occurrence of butterflies at Jiwaji University campus, Gwalior, Madhya Pradesh. Bugs R All, 21, 16-20.

Dey, A. et al. (2013). A Preliminary Study on Avifaunal Species Diversity of Maharaja Bir Bikram College Campus, Tripura, North East India. International Multidisciplinary Research Journal, 3(2), 36-43.

Grimmett, R.C., Inskipp, C. and Inskipp, T. (1998). Birds of the Indian Subcontinent. Oxford University Press, New Delhi.

Jain, N.K., Patel, S.N. and Patel, M.V. (2005). Birds of Gujarat University Campus, Ahmedabad. Zoos' Print Journal, 20(12), 2111-2113.

Mandal, R. and Aditya (Bandyopadhyay), S. (2017). An observation on the Odonata diversity in and around Sarojini Naidu College campus, Kolkata, West Bengal, India. International Journal of Entomology Research, 2(4), 31-34.

Mohapatra, R., Mishra, A.K., Mishra, S., Parida, S.P. (2013). A preliminary assessment of butterfly diversity in Utkal University campus, Odisha. Zoo's Print, XXVIII 9

Nair, A.V., Mitra, P. and Bandyopadhyay, S.A. (2014). Studies on the diversity and abundance of butterfly (Lepidoptera: Rhopalocera) fauna in and around Sarojini Naidu College campus, Kolkata, West Bengal, India. Journal of Entomology and Zoology Studies, 2(4), 129-134.

Reaka-Kudla, M.L., Wilson, D.E., Wilson, E.O. (Eds.), (1997). Biodiversity II, Henry Press, Washington D. C. pp. 1-3.

\section{Conflicts of Interest:}

The author declare that the research was conducted in the absence of any commercial or economic associations that could be construed as a potential conflict of interest

Reginald, L.J. et al. (2014). Status and ecology of the birds of an urban college campus, Coimbatore, Tamil Nadu, India. PSGCAS Search: A Journal of Science and Technology, 2(1), 1-9.

Subramanian, K. A. (2014). A checklist of Odonata (Insecta) of India. Zoological Survey of India, 31pp.

Tiple, A.D. (2011). Butterflies of Vidarbha region Maharashtra, India; a review with and implication for conservation. Journal of Threatened Taxa, 3(1), 1469-1477.

Tiple, A.D. (2012). Butterfly species diversity, relative abundance and status in Tropical Forest Research Institute, Jabalpur, Madhya Pradesh, central India. Journal of Threatened Taxa, 4(7), 2713-2717.

Tiple, A.D., Deshmukh, V.P., Dennis, R.L.H. (2006). Factors influencing nectar plant resource visits by butterflies on a university campus: implications for conservation. Nota Lepidopteralogica, 28, 213-224.

Tiple, A.D., Khurad, A.M., Dennis, R.L.H. (2007). Butterfly diversity in relation to a human-impact gradient on an Indian university campus. Nota lepidopterologica, 30(1), 179-188.

Varshney, R.K. (1983). Index Rhopalocera Indica Part II. Common names of butterflies from India and neighbouring countries. Records of Zoological Survey of India. Occassional Paper No. 47: 1-49.

Wadatkar, J.S. (2001). Checklist of birds from Amaravati University Campus, Maharastra. Zoos' Print Journal, 16(5), 497-499.

Wheeler, A.G. (2008). College campuses: patches of insect diversity, opportunities for entomological discovery and means for enhancing ecological literacy. American Entomologist

Wynter-Blyth, M.A. (1957). Butterflies of the Indian Region. Bombay Natural History Society, Mumbai, 523pp. 